\title{
Emissions Of Greenhouse Gases From Diesel Consumption In Agricultural Production Of Turkey
}

\author{
Beran ADAY ${ }^{1}$, Can ERTEKIN 1 , Fatih EVRENDILEK²
}

\begin{abstract}
Agricultural sector is both energy consumer in the form of human labor, fossil fuels, electricity, seeds, fertilizer, and pesticides and energy producer in the form of food, feed, and biofuels. High agricultural use of energy inputs results in adverse environmental issues such as global climate change, pollution of water, soil and air, and unsustainable agricultural production. In this study, 35 agricultural crops such as cereals, fruits, and vegetables were evaluated in terms of consumption of diesel fuel during their production process including soil preparation, fertilization, sowing, spraying, harvesting and transportation, based on minimum and maximum values reported in related literature. Greenhouse gas (GHG) emissions from diesel consumption can be expressed as total carbon dioxide equivalent $\left(\mathrm{CO}_{2 \mathrm{eq}}\right)$ emissions $\left(2.76 \mathrm{~kg}\right.$ per liter). a map showing total $\mathrm{CO}_{2 \mathrm{eq}}$ emissions from diesel consumption for agricultural production. Our estimates showed that minimum and maximum GHG emissions varied between 0.48 and $3.75 \mathrm{Tg} \mathrm{CO}_{2 \text { eq }}$ for wheat, 17.15 and $65.45 \mathrm{Gg}$ $\mathrm{CO}_{2 \text { eq }}$ for chickpea, and 0.088 and $0.153 \mathrm{Tg} \mathrm{CO}_{2 \text { eq }}$ for tomatoes, respectively. In order to reduce diesel-related GHG emissions, there is an urgent need for innovative agricultural practices and technologies to be put into place.
\end{abstract}

\section{Introduction}

Energy is vital to socio-economic development and health of all the countries. However, heavy reliance on fossil fuels has caused serious global and regional concerns such as climate change, conflicts, and refugees. Anthropogenic greenhouse gas (GHG) emissions from fossil fuel consumption are the most significant driver of climate change, with carbon dioxide $\left(\mathrm{CO}_{2}\right)$ as the primary GHG (Ozturk et al., 2016; Cabuk, 2011; Ozcan, 2016). Total GHG emissions in Turkey was estimated to increase by $125 \%$ relative to 1990 to 467.6 million tonnes $\mathrm{CO}_{2}$ equivalent $\left(\mathrm{CO}_{2 \mathrm{eq}}\right)$ in 2014, with the biggest four shares belonging to energy-related sources $(72.5 \%)$, industrial processes $(13.4 \%)$, agriculture $(10.6 \%)$, and wastes $(3.5 \%)$. $\mathrm{CO}_{2 \text { eq }}$ per capita was 3.77 tonnes in 1990 and reached 6.08 tonnes in 2014 (www.tuik.gov.tr).

Different forms of energy, in particular, considerable amounts of fossil fuels are intensively applied in in all field-to-fork stages of agricultural production directly or indirectly in order to produce food for growing population. Diesel fuel is the most commonly used energy source in different agricultural processes such as soil tillage, sowing, fertilization, spraying, harvesting, and transportation (Houshyar et al., 2015). In this study, diesel consumption for the production of 35 crops in 81 cities in Turkey was derived from related literature, converted to minimum and maximum values of total $\mathrm{CO}_{2 \text { eq }}$ emissions and interpolated on a national scale using universal krigging.

1 Akdeniz University, Faculty of Agriculture, Dept. of Farm Machinery and Technologies Engineering, Antalya, TURKEY.

2 Abant Izzet Baysal University, Faculty of Engineering, Dept. of Environmental Engineering, Bolu, TURKEY. 


\section{Materials And Methods}

Data about amount and area agricultural production were obtained from TUIK (Turkey Statistics Institution) for 81 cities across Turkey for 35 products in 2015. Sitespecific minimum and maximum values of diesel fuel consumption (L.ha ${ }^{-1}$ ) were derived from related literature (Table 1). These minimum and maximum values were converted to total $\mathrm{CO}_{2 \text { eq }}$ emission using the multiplier of by $2.76 \mathrm{~kg} \mathrm{CO}_{2} \cdot \mathrm{L}^{-1}$ diesel fuel and were extrapolated multiplying them by agricultural production area for each city (Abdi et al., 2012; Mirasi et al., 2015). Using the interpolation method of universal kriging, total $\mathrm{CO}_{2 \text { eq }}$ emissions were mapped at the national scale.

Table 1. Minimum and maximum values of diesel fuel consumption per hectare in production of different agricultural crops.

\begin{tabular}{|c|c|c|c|}
\hline \multirow[b]{2}{*}{ Product } & \multicolumn{2}{|c|}{\begin{tabular}{|l|l|}
$\begin{array}{l}\text { Diesel } \\
\left(\text { L.ha }^{-1}\right)\end{array}$ & consumption \\
\end{tabular}} & \multirow[b]{2}{*}{ References } \\
\hline & Min & Max & \\
\hline Wheat & 21.99 & 172.50 & $\begin{array}{l}\text { Gozubuyuk et al., 2012; Tipi et al., 2009; Yaldiz et al., 1993; } \\
\text { Eren et al., 2006; Canakci et al., 2005; Karaagac et al., } 2012\end{array}$ \\
\hline Barley & 29.53 & 60.50 & Yaldiz et al., 1993; Baran and Gokdogan, 2014 \\
\hline Green bean & 27.19 & 43.63 & Yaldiz et al., 1993 \\
\hline Chickpea & 17.29 & 66.00 & Dellal et al., 2007; Yaldiz et al., 1993 \\
\hline Soybean & 48.30 & 48.30 & Yaldiz et al., 1993 \\
\hline Sugarbeet & 41.49 & 105.00 & Erdal et al., 2007; Yaldiz et al., 1993; Topak et al, 2010 \\
\hline Sunflower & 39.84 & 96.00 & $\begin{array}{l}\text { Baran and Karaagac, 2014; Yaldiz et al., 1993; Uzunoz et al., } \\
\text { 2008; }\end{array}$ \\
\hline Cotton & 44.82 & 337.20 & $\begin{array}{l}\text { Eren and Ozturk, 2006; Yaldiz et al., 1993; Canakci et al., } \\
\text { 2005; Sehr, 2012; Dagistan et al., 2009; Yilmaz et al., 2005; } \\
\text { Polat et al., 2006 }\end{array}$ \\
\hline Rose & 26.33 & 113.89 & Akbolat et al., 2006; Gokdogan and Demir, 2013 \\
\hline Potato & 22.62 & 232.80 & Dellal et al., 2007; Yaldiz et al., 1993 \\
\hline Tomatoes & 169.80 & 295.70 & Cetin and Vardar 2008; Canakci et al., 2005; 64 \\
\hline Watermelon & 72.40 & 172.78 & Baran and Gokdogan, 2014b; Canakci et al., 2005 \\
\hline Melon & 91.70 & 169.27 & Baran and Gokdogan, 2014b; Canakci et al., 2005 \\
\hline Apple & 14.89 & 255.17 & Yilmaz et al., 2010; Ekinci et al., 2005 \\
\hline Quince & 143.62 & 143.62 & Gundogmus, 2013a \\
\hline Apricot & 110.10 & 187.15 & Gundogmus, 2006; Gezer et al., 2003 \\
\hline Cherry & 91.00 & 183.80 & Kizilaslan, 2009; Demircan et al., 2006 \\
\hline Peach & 168.60 & 245.79 & Gokdogan, 2011; Goktolga et al., 2006 \\
\hline Mandarin & 254.70 & 254.70 & Ozkan et al., 2004 \\
\hline Orange & 248.40 & 337.50 & Ozkan et al., 2004; Dellal et al., 2007 \\
\hline
\end{tabular}




\begin{tabular}{|l|l|l|l|} 
Lemon & 234.40 & 344.40 & Ozkan et al., 2004; Bilgili, 2012 \\
\hline Grape & 70.20 & 134.00 & Ozkan et al., 2007; Dellal et al., 2007 \\
\hline Pomegranate & 26.92 & 85.60 & Canakci, 2010; Akcaoz et al., 2009 \\
\hline Pistachio & 41.78 & 68.80 & Saglam et al., 2012; Kulekci and Aksoy, 2013 \\
\hline Banana & 178.00 & 178.00 & Gundogmus, 2013b \\
\hline Sorgum & 92.60 & 92.60 & Eren and Ozturk, 2011 \\
\hline Maize (for silage) & 23.09 & 66.77 & Barut et al., 2011 \\
\hline Maize & 46.82 & 134.80 & Yaldiz et al., 1993; Erdogan, 2009; Canakci et al., 2005 \\
\hline Sesame & 87.80 & 87.80 & Canakci et al., 2005 \\
\hline Colza & 76.61 & 77.97 & Baran et al., 2014; Arikan, 2011 \\
\hline Paddy & 204.00 & 204.00 & Dellal et al., 2007 \\
\hline Tobacco & 66.60 & 66.60 & Dellal et al., 2007 \\
\hline Lentil & 60.60 & 60.60 & Dellal et al., 2007 \\
\hline Hazelnut & 54.00 & 54.00 & Dellal et al., 2007 \\
\hline Olive & 57.60 & 57.60 & Dellal et al., 2007 \\
\hline
\end{tabular}

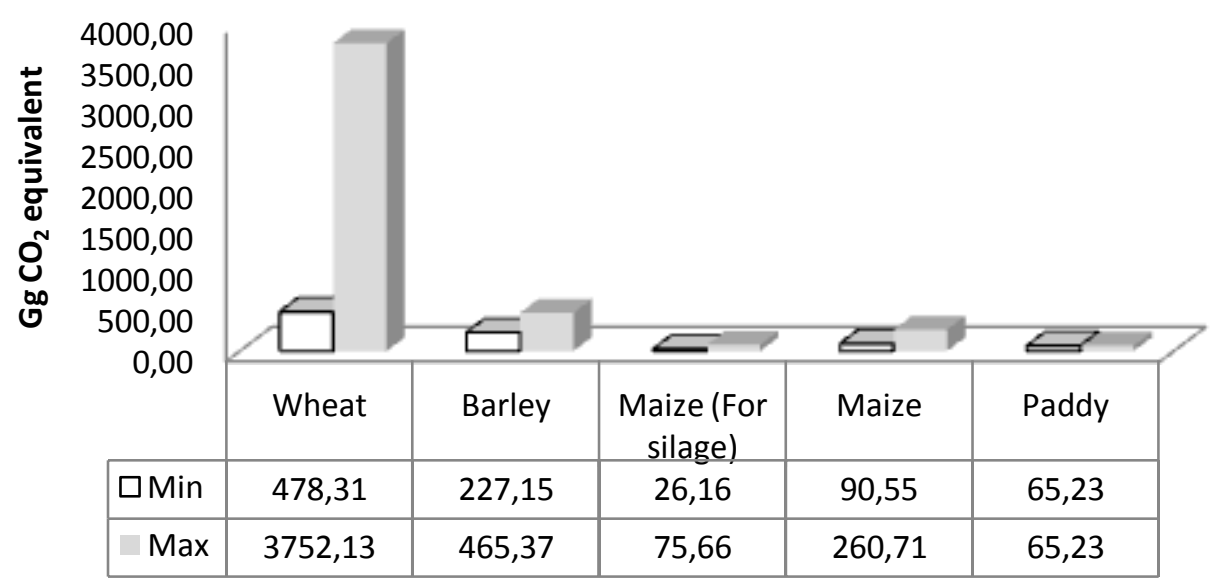

Fig. 1. $\mathrm{CO}_{2}$-equivalent emissions from diesel consumption for growing grains in Turkey.

Maximum $\mathrm{CO}_{2 e q}$ emission after grains belonged to industrial, tuberous and feed crops. In particular, for sugarbeet, sunflower, cotton and potato production, the differences between minimum and maximum $\mathrm{CO}_{2 e q}$ emissions are very bigh because of different practices adopted during the growing season (Fig. 3).

\section{Results}

The biggest share of agricultural production in Turkey belongs to grains. Diesel consumption for wheat production ranges from 21.99 to 172.50 L.ha-1 which correspond to 478.3 and $3752.1 \mathrm{Gg} \mathrm{CO}_{2 \mathrm{eq}}$, respectively. These values were lower for barley, maize, 
maize for silage, and paddy (Fig. 1). There exist very limited studies about leguminosae plants, and $\mathrm{CO}_{2 \text { eq }}$ emissions varied between 17.2 and $65.5 \mathrm{Gg}$ for chickpea, 37.4 Gg for lentil and 4.9 Gg for soybean (Fig. 2).

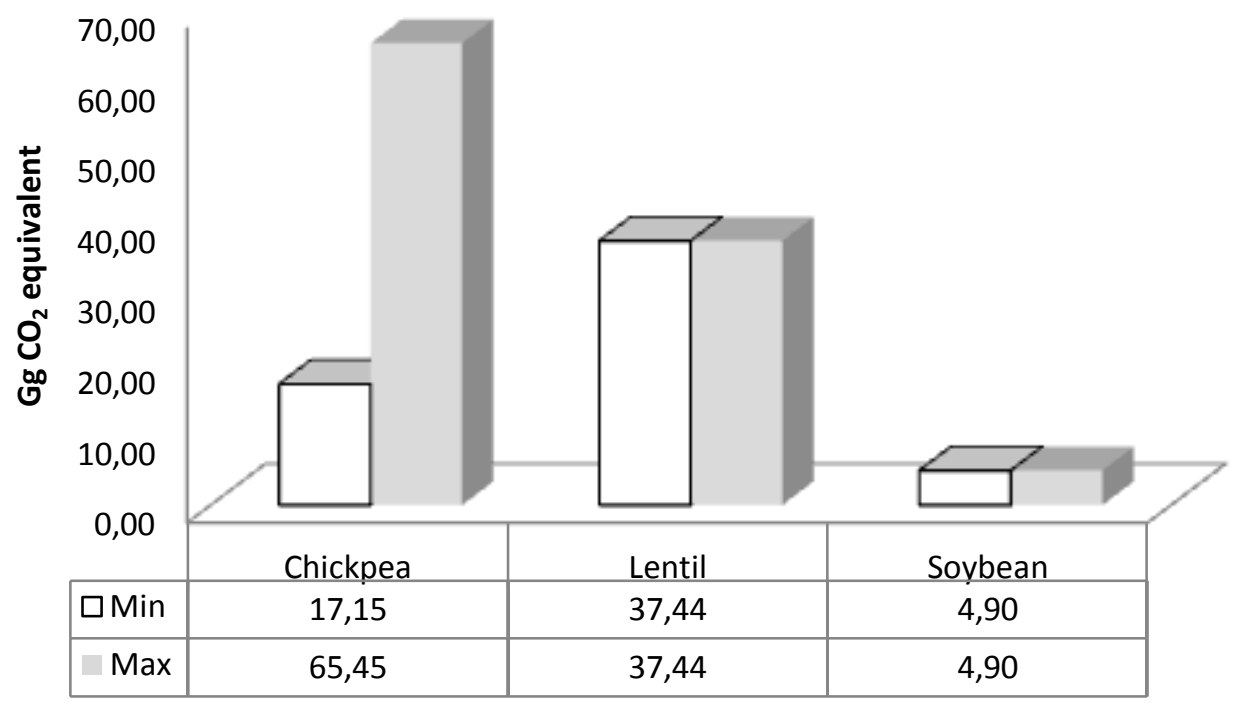

Fig. 2. $\mathrm{CO}_{2}$-equivalent emissions from diesel consumption for growing leguminosae crops in Turkey.

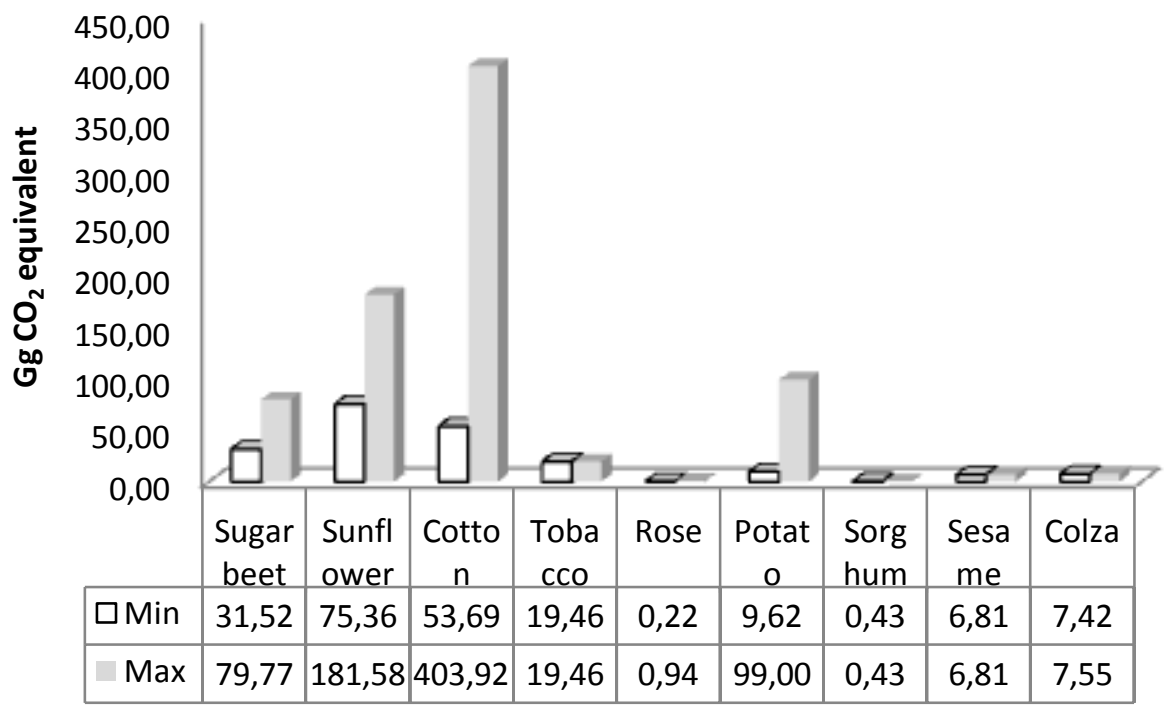

Fig. 3. $\mathrm{CO}_{2}$-equivalent emissions from diesel consumption for growing industrial, tuberous and feed crops in Turkey. 
Diesel consumption was highest for tomato production among the vegetables considered. $\mathrm{CO}_{2 \mathrm{eq}}$ emissions from the production of vegetables varied between 3.76 and 152.75 Gg (Fig. 4).

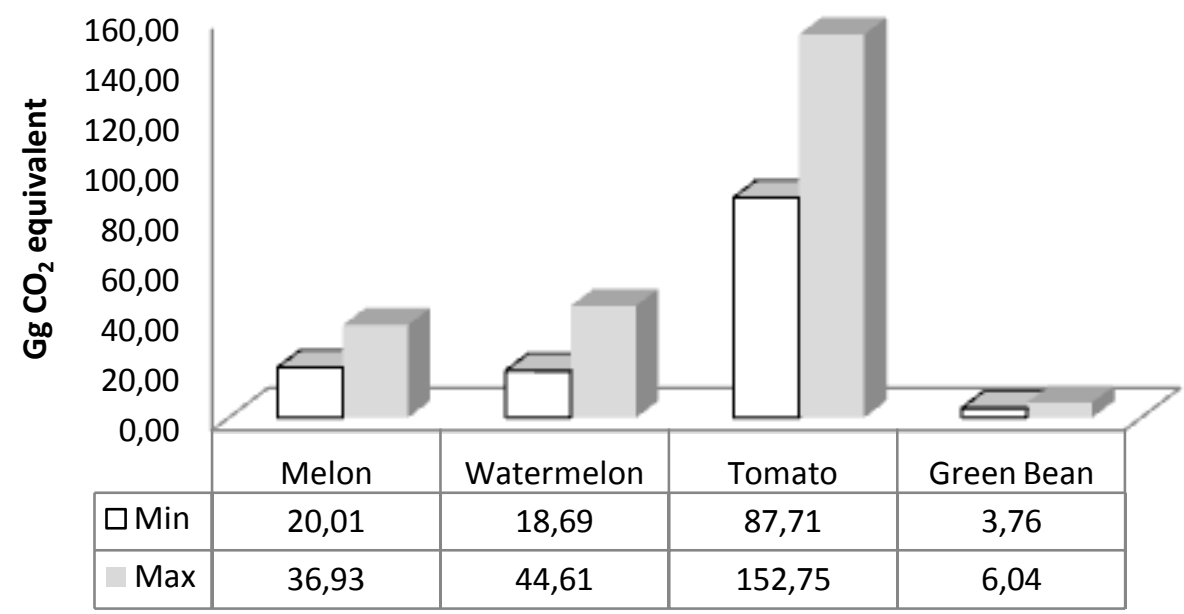

Fig. 4. $\mathrm{CO}_{2}$-equivalent emissions from diesel consumption for growing vegetables in Turkey.

There exists many studies about fruit production in related literature, and minimum and maximum values of total $\mathrm{CO}_{2 \mathrm{eq}}$ emissions ranged between 2.28 and $133.05 \mathrm{Gg}$ for quince and olive, respectively (Figs. 5 and 6). Minimum and maximum values of total $\mathrm{CO}_{2 \mathrm{eq}}$ emissions from diesel consumption for the production of these 35 crops during the growing season were interpolated based on the universal krigging method and presented in Figs. 7 and 8.

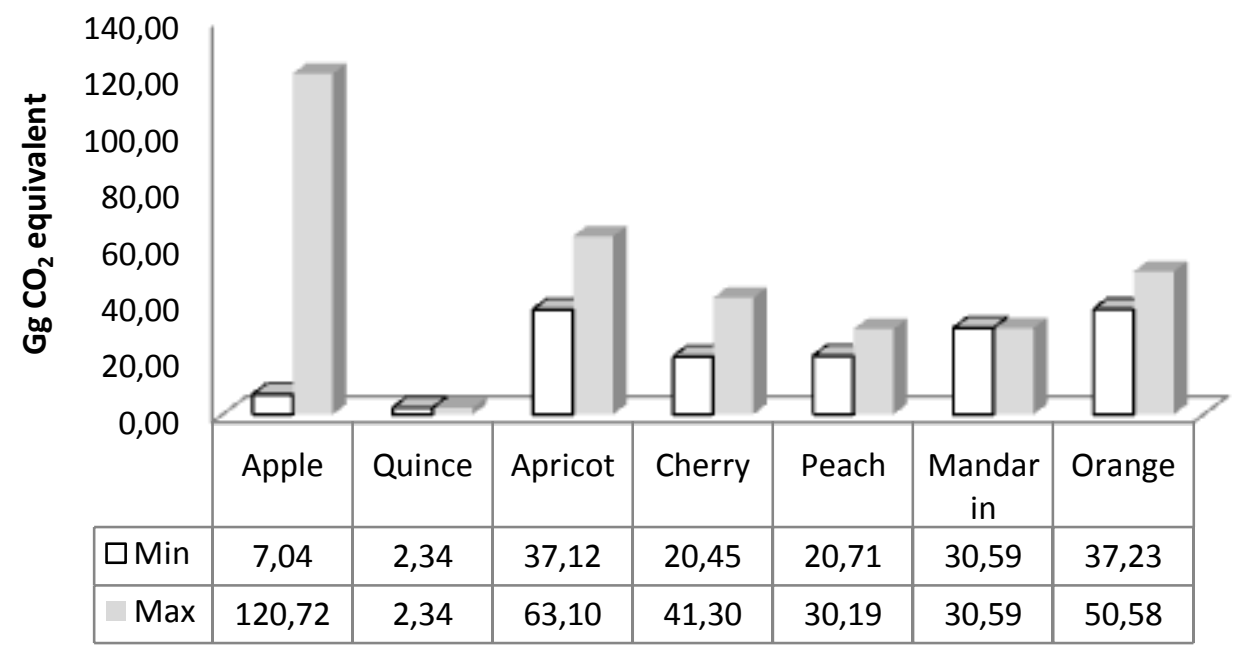

Fig. 5. $\mathrm{CO}_{2}$-equivalent emissions from diesel consumption for growing fruits in Turkey. 


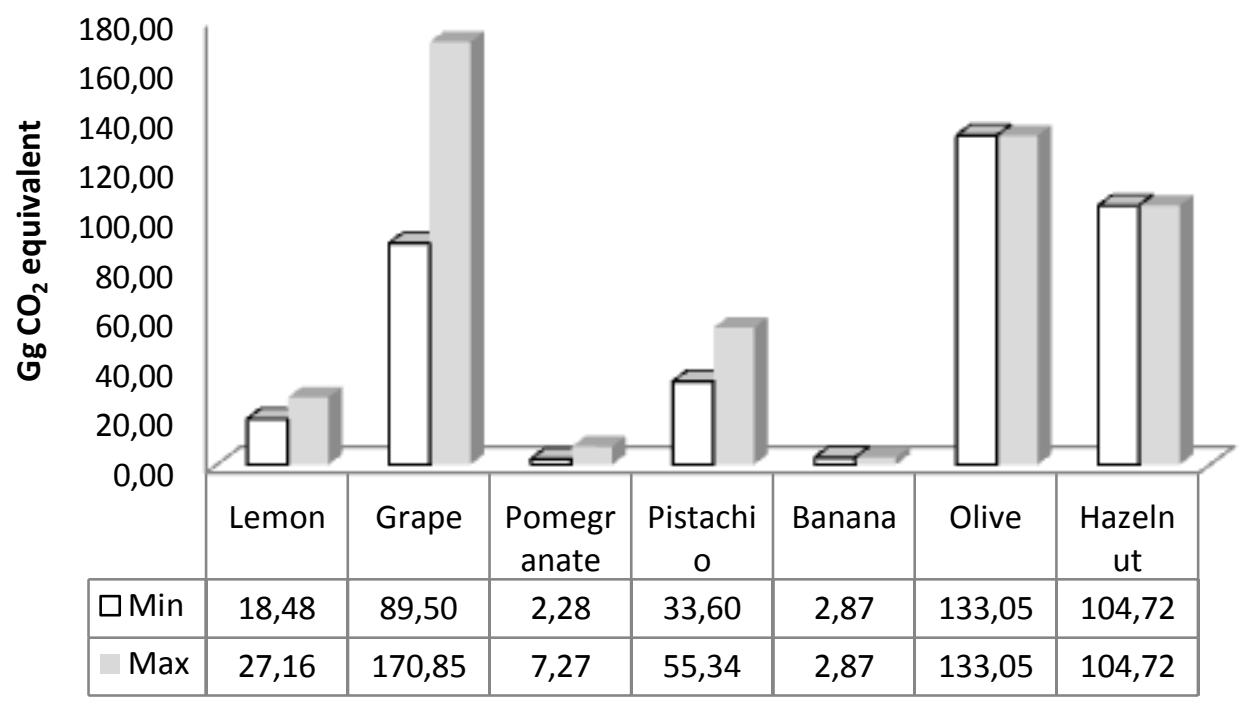

Fig. 6. CO2-equivalent emissions from diesel consumption for growing fruits in Turkey.

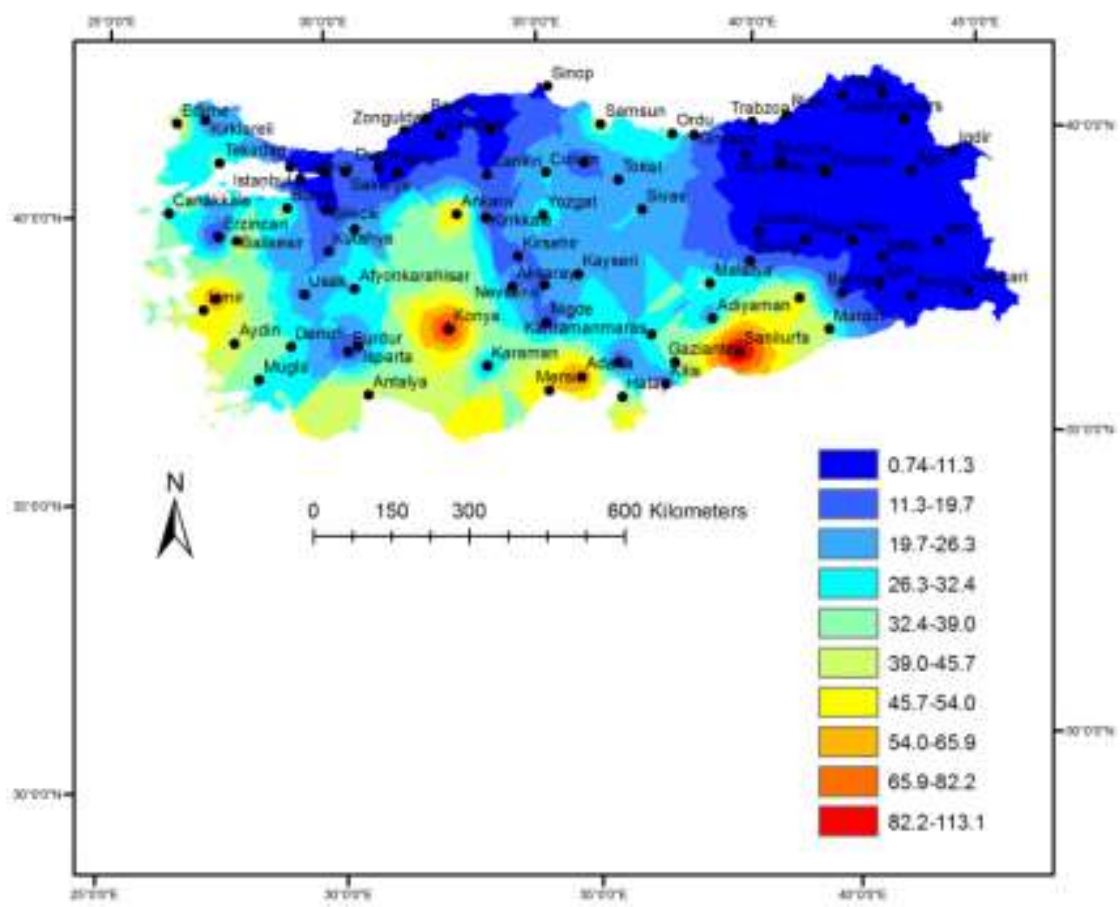

Fig. 7. National map of minimum total $\mathrm{CO}_{2}$-equivalent emissions $\left(\mathrm{Gg}=10^{6} \mathrm{~kg}\right)$ from diesel consumption for agricultural production of 35 crops in 2015, based on the interpolation method of universal kerigging. 


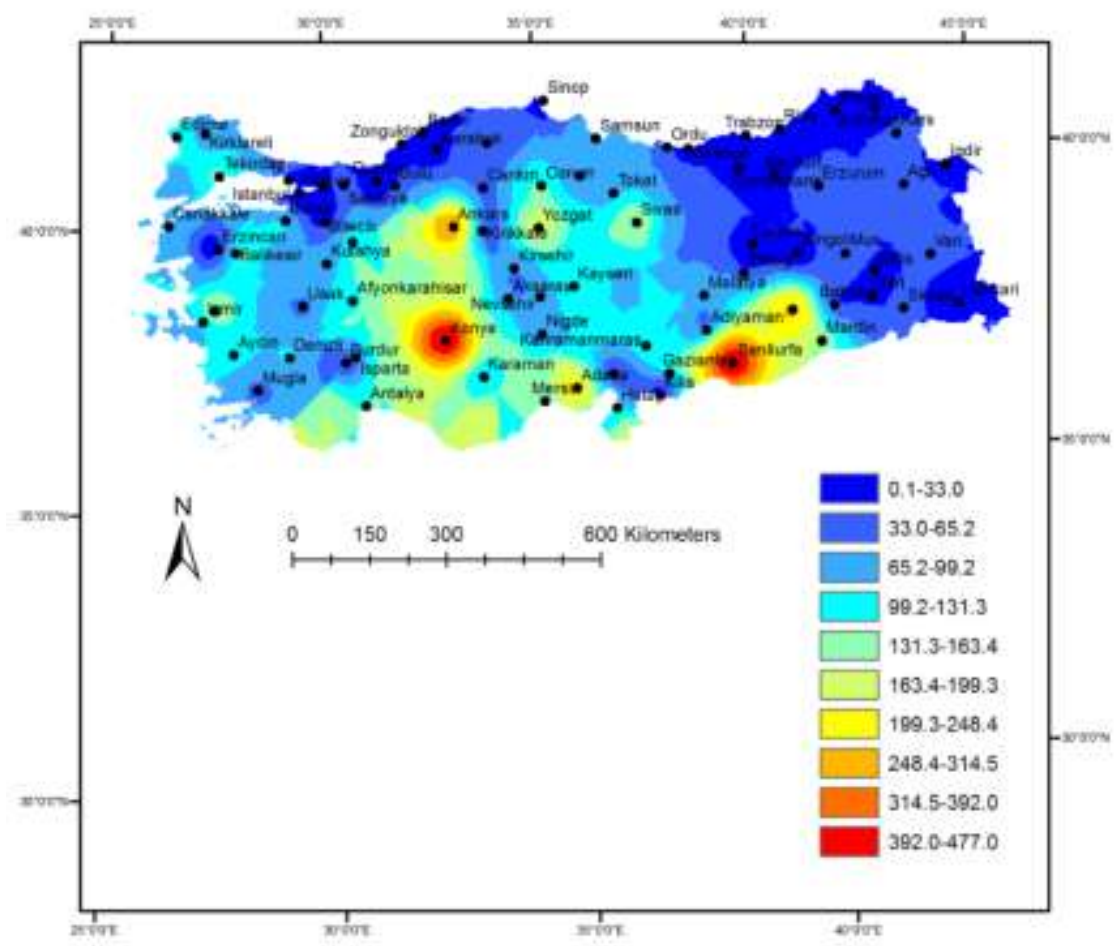

Fig. 8. National map of maximum total $\mathrm{CO}_{2}$-equivalent emissions $\left(\mathrm{Gg}=10^{6} \mathrm{~kg}\right)$ from diesel consumption for agricultural production of 35 crops in 2015, based on the interpolation method of universal krigging.

According to the interpolation maps in Figs. 7 and 8 generated using the universal krigging method, minimum and maximum total $\mathrm{CO}_{2 \mathrm{eq}}$ emissions from the entire diesel consumption for the production of the 35 crops were highest near Konya in central Anatolia and Gaziantep in southeastern Anatolia.

\section{Conclusions}

In agriculture, different practices such as soil tillage, sowing, fertilizing, spraying, harvesting and transportation generally involve using tractors, and thus, diesel fuel consumption. Total $\mathrm{CO}_{2 \text { eq }}$ emissions from total agricultural diesel consumption were estimated to vary between 1821.5 and 6606.7 thousand tonnes. The interpolation method of universal krigging led to minimum and maximum values of total $\mathrm{CO}_{2 \mathrm{eq}}$ emissions in 2015 that ranged from 0.7 to $113 \mathrm{Gg}$ and from 0.1 to $477 \mathrm{Gg}$, respectively. In order to decrease total $\mathrm{CO}_{2 \mathrm{eq}}$ emissions, energy efficiency of tractors should be improved, and alternative renewable energy inputs (e.g. biofuels) should be sought to minimize reliance on fossil fuels. It is of urgent need to identify innovative practices and technologies to improve agricultural energy budget, and its spatio-temporal dynamics in 
accordance with social acceptance and ecological requirements not only in Turkey but also globally.

\section{References}

Abdi R.; Taki M.; Akbarpour M.; 2012. An analysis of energy input-output and emissions of greenhouse gases from agricultural productions. International Journal of Natural and Engineering Sciences 6: 73-79.

Akbolat D.; Ekinci K.; Demircan V.; 2006. Energy input-output and economic analysis of rose production in Turkey. Journal of Agronomy 5: 570-576.

Akcaoz H.; Ozcatalbas O.; Kizilay H.; 2009. Analysis of energy use for pomegranate production in Turkey. Journal of Food, Agriculture and Environment 7: 475-480.

Arikan M.; 2011. Adana Ilinde Kolza Uretiminde Enerji Kullanımı. Cukurova Universitesi Fen Bilimleri Enstitusu, Tarim Makinaları Anabilim Dalı, Adana (in Turkish).

Baran M.F.; Gokdogan O.; 2014a. Energy Input-Output Analysis of Barley Production In Thrace Region of Turkey. American-Eurasian J. Agric. and Environ. Sci. 14:1255-1261.

Baran M.F.; Gokdogan O.; 2014b. Karpuz Ve Kavun Yetistiriciliginde Enerji Girdi-Cikti Analizi: Kurklareli Ili Ornegi. Anadolu Tarim Bilim. Derg. 29: 217-224 (in Turkish).

Baran M.F.; Gokdogan O.; Karaagac H.A.; 2014. Kanola Uretiminde Enerji Kullanım Etkinliğinin Belirlenmesi (Kirklareli Ili Ornegi). Turk Tarim ve Doga Bilimleri Dergisi 1: 331-337 (in Turkish).

Baran M.F.; Karaagac H.A.; 2014. Kirklareli Kosullarında Ikinci Urun Aycicegi Uretiminde Enerii Kullanım Etkinliginin Belirlenmesi. Turk Tarim ve Doga Bilimleri Dergisi 1: 117-123 (in Turkish).

Barut Z.B.; Ertekin C.; Karaagac H.A.; 2011. Tillage effects on energy use for corn silage in Mediterranean Coastal of Turkey. Energy 36: 5466-5475.

Bilgili M.E., 2012. Limon üretiminde enerji kullanım etkinliğinin belirlenmesi: Adana ili örneği. Tarım Makinalar1 Bilimi Dergisi 8: 199-203 (in Turkish).

Cabuk S.O.; 2011. Kuresel Isinmaya Yol Acan Sera Gazi Emisyonlarindaki Artis Ile Mucadelede Iktisadi Araclarin Rolunun Degerlendirilmesi: Enerji Sektoru Ornegi. Doktora Tezi, Sosyal Bilimler Enstitusu, Ankara Universitesi, Ankara (in Turkish).

Canakci M., 2010. Energy use pattern and economic analyses of pomegranate cultivation in Turkey. African Journal of Agricultural Research 5: 491-499.

Canakci M.; Topakci M.; Akinci I.; Ozmerzi A.; 2005. Energy use pattern of some field crops and vegetable production: Case study for Antalya Region, Turkey. Energy Conversion and Management 46: 655666.

Cetin B.; Vardar A.; 2008. An economic analysis of energy requirements and input costs for tomato production in Turkey. Renewable Energy 33: 428-433.

Dellal I.; Ozat H.E.; Ozudogru T.; 2007. Tarimda mazot kullanimi ve mazot destekleri. Yayin No: 163, ISBN: 978-975-407-238-9 (in Turkish).

Demircan V.; Ekinci K.; Keener H.M.; Akbolat D.; Ekinci C.; 2006. Energy and economic analysis of sweet cherry production in Turkey: A case study from Isparta province. Energy Conversion and Management 47: 1761-1769.

Ekinci K.; Akbolat D.; Demircan V.; Ekinci C.; 2005. Isparta Ili Elma Uretiminde Enerji Kullanım Etkinliginin Belirlenmesi. III. Yenilenebilir Enerji Kaynaklari Sempozyumu ve Sergisi, 19-21 Ekim, Mersin (in Turkish).

Erdal G.; Esengun K.; Erdal H.; Gunduz O.; 2007. Energy use and economical analysis of sugar beet production in Tokat province of Turkey. Energy 32: 35-41.

Erdogan Y.; 2009. Tarimsal Uretimde Enerji Girdi Cikti Analizlerinde Kullanilacak Internet Tabanli Bir Yazilimin Gelistirilmesi. Cukurova Universitesi Fen Bilimleri Enstitusu Yuksek Lisans Tezi, Adana (in Turkish). 
Eren O.; Ozturk H.H.; 2006. An Analysis of Energy Utilization for Sustainable Wheat and Cotton Production in Southeastern Anatolia Region of Turkey, Journal of Sustainable Agriculture, 29:1, 119-130.

Eren O.; Ozturk H.H.; 2011. Cukurova Bolgesinde Tatli Sorgum (Sorghum bicolor (L.) Moench) Uretiminde Enerji Kullanimi. C.U. Fen ve Muhendislik Bilimleri Dergisi 26 (in Turkish).

Gezer I.; Acaroglu M.; Haciseferogullari H.; 2003. Use of energy and labour in apricot agriculture in Turkey. Biomass and Bioenergy 24: 215-219.

Gokdogan O.; 2011. Isparta Ili Seftali Yetistiriciliginde Enerji Girdi Cikti Analizi. E.U. Fen Bilimleri Enstitüsü Dergisi 4: 145-155 (in Turkish).

Gokdogan O.; Demir F.; 2013. Isparta Yoresinde Yag Gulu Uretiminde Enerji Girdi Cikti Analizi. Tarİm Bilimleri Dergisi 19: 33-43 (in Turkish).

Goktolga Z.G.; Gözener B.; Karkacıer O.; 2006. Seftali Uretiminde Enerji Kullanımı: Tokat İli Örneği. G.O.U. Ziraat Fakültesi Dergisi 23: 39-44 (in Turkish).

Gundogmus E.; 2006. Energy use on organic farming: A comparative analysis on organic versus conventional apricot production on small holdings in Turkey. Energy Conversion and Management 47: 3351-3359.

Gundogmus E.; 2013a. Energy Use Patterns And Econometric Models Of Quince Production. Actual Problems Of Economics 5(143).

Gundogmus E.; 2013b. Energy Use Pattern And Econometric Models Of Banana Production. Actual Problems Of Economics, 3(141).

Karaagac H.A.; Aykanat S.; Coskun M.A.; Simsek M.; 2012. Bugday Tariminda Farkli Ekim Tekniklerinin Enerji Bilancosu. 27. Tarimsal Mekanizasyon Ulusal Kongresi, 5-7 Eylul 2012, Samsun, 169-173 (in Turkish).

Kizilaslan H.; 2009. Input-output energy analysis of cherries production in Tokat Province of Turkey. Applied Energy 86: 1354-1358.

Kulekci M.; Aksoy A.; 2013. Input-Output Energy Analysis in Pistachio Production of Turkey. Environmental Progress \& Sustainable Energy 32(1).

Mirasi, A., Samadi, M., Rabiee, A.H., 2015. An analytical method to survey the energy input-output and emissions of greenhouse gases from wheat and tomato farms in Iran. Biological Forum-An International Journal 7: 52-58.

Ozcan M.; 2016. Estimation of Tukey's GHG emissons from electricity generation by fuel types. Renewable and Sustainable Energy Reviews 53: 832-840.

Ozkan B.; Akcaoz H.; Karadeniz F.; 2004. Energy requirement and economic analysis of citrus production in Turkey. Energy Conversion and Management 45: 1821-1830.

Ozkan B.; Fert C.; Karadeniz C.F.; 2007. Energy and cost analysis for greenhouse and open-field grape production. Energy 32: 1500-1504.

Ozturk F.; Keles M.; Evrendilek F.; 2016. Quantifying rates and drivers of change in long-term sector- and country-specific trends of carbon dioxide-equivalent greenhouse gas emissions. Renewable \& Sustainable Energy Reviews 65: 823-831.

Polat R.; Copur O.; Saglam R.; Saglam C.; 2006. Energy Use Pattern and Cost Analysis of Cotton Agriculture: A Case Study for Sanliurfa, Turkey. The Philippine Agricultural Scientist 89: 368-371.

Saglam C.; Tobi I.; Kup C.F.; Cevik M.Y.; 2012. An input-output energy analysis in pistachio nut production: A case study for Southeastern Anotolia Region of Turkey. African Journal of Biotechnology 11: 1868-1871.

Sehr M.; 2012. Adana Yoresi Pamuk Uretiminde Enerji Kullanım Etkinligi Ve Maliyet Analizi. C. U. Fen Bilimleri Enstitüsü, Tarım Makinaları ABD, Adana (in Turkish).

Tipi T.; Çetin B.; Vardar A.; 2009. An analysis of energy use and input costs for wheat production in Turkey. Journal of Food, Agriculture \& Environment 7: 352-356.

Topak R.; Suheri S.; Acar B.; 2010. Comparison of energy of irrigation regimes in sugar beet production in a semi-arid region. Energy 35: 5464-5471.

TUIK (Turkey Statistics Institution). www.tuik.gov.tr.

Uzunoz M.; Akcay Y.; Esengun K.; 2008. Energy Input-output Analysis of Sunflower Seed (Helianthus annuus L.) Oil in Turkey, Energy Sources, Part B: Economics, Planning, and Policy 3: 215-223.

Yilmaz I.; Akcaoz H.; Ozkan B.; 2005. An analysis of energy use and input costs for cotton production in Turkey. Renewable Energy 30: 145-155. 
Yilmaz I.; Ozalp A.; Aydogmus F.; 2010. Antalya ili bodur elma üretiminde enerji kullanım etkinliğinin belirlenmesi: Elmalı ilçesi ornegi. Akdeniz Universitesi Ziraat Fakultesi Dergisi 23: 93-97 (in Turkish). 